\title{
NAUTAKARJAN KIVENNÄISAINEIDEN SYÖNNISTÄ LAITUMELLA. III
}

\author{
IRJA UotILA \\ Maatalouden tutkimuskeskus, Kotieläinhoidon tutkimuslaitos, Tikkurila
}

Saapunut 11. 5. 1962 .

Tutkimuksen ensimmäinen osa on julkaistu 1958 (3) ja toinen osa 1959 (4). Näissä tutkimuksissa on vertailtu rehusuolaseosten raaka-aineita toisiinsa ja kauppavalmisteisia seoksia sekä lypsylehmille että hiehoille. Näissä kokeissa olivat halutuimmat kivennäisrehut mononatriumfosfaatti, luujauho ja ruokasuola. Hiehot söivät laitumella yleensä runsaammin kivennäisrehuja kuin lehmät.

Tähän tutkimukseen sisältyvät vv. 1959 ja 1960 kesällä suoritetut kokeet, joita oli yhteensä 7 koetta sekä lehmillä että hiehoilla. Kokeet on suoritettu maatalouden tutkimuskeskuksen Ayrshirekarjassa kuten kahtena edellisenäkin kesänä. Kokeitten suoritus on ollut samanlainen kuin aikaisemmissakin kokeissa $(3,4)$.

\section{Vuoden 1959 kokeet}

Leh mät

Lehmien keskimääräinen elopaino oli $507 \mathrm{~kg}$ ja keski-ikä $6.1 \mathrm{v}$. Lehmien lukumäärä ja jakaantuminen eri tuotosluokkiin eri kokeissa on esitetty taul. 1. Taul. 2 on lehmät ryhmitetty sen ajan (p) mukaan, mikä niillä oli jäljellä seuraavaan poikimiseen. Lehmillä suoritettiin kesän kuluessa neljä koetta, joista tulokset on esitetty taul. 3.

K o e I. Koetta $(8 / 6-8 / 7)$ varten jaettiin karja kahteen ryhmään runsastuottoisiin (A) ja vähätuottoisiin (B). Taul. 1 käy ilmi kummankin ryhmän keskimääräinen maitotuotos. Ryhmää A laidunnettiin nurminata-timoteivaltaisella ja ryhmää B koiranheinä-nurminatavaltaisella laidunlohkolla. Laidunruohon kasvikoostumus ei siis ollut täysin sama, koska ei ollut käytettävissä aivan samanlaisia lohkoja. Kokeen aikana saivat kaurajauhoja + melassileikettä lisärehuksi ne lehmät, joiden ravinnontarve maidontuotantoa varten oli yli 7 ry.

Kokeessa sai kumpikin ryhmä syödä vapaasti rehusuolaseosta IV, luujauhoja 
Kokeissa käytetyt kivennäisrehut:

Mineral supplemets used in the trials:

Ruokintakalkki - Limestone (calcite)
Rehuliitu - Chalkstone
Ruokintadolomiitti - Dolomite limestone
Rehufosfaatti - Dicalcium phosphate
Luujauho - Bone meal

Mononatriumfosfaatti - Monosodiumphosphate

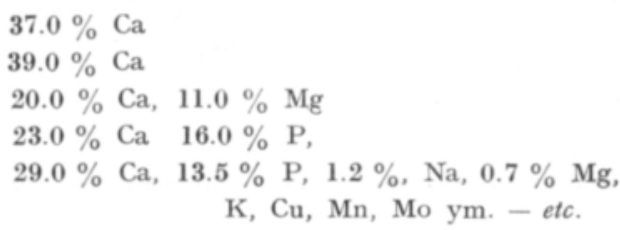

$19.9 \% \mathrm{P}, \quad 14.7 \% \mathrm{Na}$
Rehusuolaseos I

Fodder salt mixture I

$53.000 \%$ rehufosfaattia dicalciumphosphate

$42.180 \%$ ruokintakalkkia limestone

$4.656 \%$ ruokasuolaa common salt

$0.150 \%$ kuparisulfaattia coppersulfate

$0.010 \%$ kobolttisulfaattia cobaltsulfate

$0.004 \%$ kaliumjodidia potassiumiodide

$8.5 \%$ P, $27.0 \% \mathrm{Ca}$, $1.2 \% \mathrm{Na}$
Rehusuolaseos IV Fodder salt mixture $I V$

$50.000 \%$ mononatriumfosfaattia monosodiumphosphate

$40.000 \%$ rehufosfaattia dicalciumphosphate

$\mathbf{9 . 7 6 0 \%}$ magnesiumkarbonaattia magnesiumcarbonate

$0.076 \%$ rautasulfaattia ferrous sulfate

$0.150 \%$ kuparisulfaattia coppersulfate

$0.010 \%$ kobolttisulfaattia cobaltsulfate

$0.004 \%$ kaliumjodidia potassiumiodide

$15.0 \% \mathrm{P}, 8.0 \% \mathrm{Ca}$,

$10.0 \% \mathrm{Na}, 2.0 \% \mathrm{Mg}$
Rehusuolaseos V

Fodder salt mixture $\boldsymbol{V}$

$41.000 \%$ dinatriumfosfaattia disodiumphosphate

$39.000 \%$ rehufosfaattia dicalciumphosphate

$5.800 \%$ ruokasuolaa common salt

$4.000 \%$ magnesiumoksidia magnesiumoxide

$0.150 \%$ kuparisulfaattia coppersulfate

$0.010 \%$ kobolttisulfaattia cobaltsulfate

$0.005 \%$ kaliumjodidia potassiumiodide

$10.000 \%$ kalajauhoja fishmeal

$10.0 \% \mathrm{P}, 10.0 \% \mathrm{Ca}$, $2.3 \% \mathrm{Mg}, 2.0 \% \mathrm{Na}$
Rehusuolaseos VI

Fodder salt mixture VI

$79.000 \%$ rehufosfaattia dicalciumphosphate

$15.000 \%$ mononatriumfosfaattia monosodiumphosphate

$6.000 \%$ magnesiumoksidia magnesiumoxide

$0.050 \%$ kuparisulfaattia coppersulfate

$0.020 \%$ kobolttisulfaattia cobaltsulfate

$0.005 \%$ kuparijodidia copperiodide

$0.100 \%$ mausteseosta aroma mixture

$16.5 \% \mathrm{P}, 18.9 \% \mathrm{Ca}$, $2.2 \% \mathrm{Na}, 3.6 \% \mathrm{Mg}$
Rehusuolaseos VII

Fodder salt mixture VII

$49.00 \%$ rehufosfaattia dicalciumphosphate

$14.00 \%$ ruokintadolomiittia dolomite limestone

$29.60 \%$ ruokasuolaa $(+\mathrm{J})$ common salt $(+\mathrm{I})$

$7.00 \%$ magnesiumoksidia magnesiumoxide

$0.28 \%$ kuparisulfaattia coppersulfate

$0.02 \%$ kobolttisulfaattia cobaltsulfate

$0.10 \%$ hajuseosta aroma mixture

$8.0 \% \mathrm{P}, 15.0 \% \mathrm{Ca}$, $11.6 \% \mathrm{Na}, \quad 5.5 \% \mathrm{Mg}$ 
Taulukko 1. Lehmien lukumäärä eri tuotosluokissa.

Table 1. Number of cows according to milk production class.

\begin{tabular}{|c|c|c|c|c|c|c|c|c|c|c|}
\hline \multirow{3}{*}{$\begin{array}{l}\text { Koe } \\
\text { Test } \\
\mathrm{n}: \mathrm{o}\end{array}$} & \multirow{3}{*}{$\begin{array}{l}\text { Ummessa } \\
\text { Not } \\
\text { lactating }\end{array}$} & \multirow{3}{*}{$\begin{array}{l}0.1- \\
5.0\end{array}$} & \multicolumn{5}{|c|}{ Maitomäärä kg/p - Milk yield kg/day } & \multirow{3}{*}{$\begin{array}{c}\text { Yht. } \\
\text { lehmiä } \\
\text { kpl }\end{array}$} & \multirow{2}{*}{\multicolumn{2}{|c|}{$\begin{array}{c}\text { Keskim. tuotos } \\
\text { eläintä kohti } \\
\text { Average yield } \\
\text { per animal }\end{array}$}} \\
\hline & & & $\begin{array}{l}5.1- \\
10.0\end{array}$ & $\begin{array}{l}10.1- \\
15.0\end{array}$ & $\begin{array}{l}15.1- \\
20.0\end{array}$ & $\begin{array}{l}20.1- \\
25.0\end{array}$ & $\begin{array}{l}25.1- \\
30.0\end{array}$ & & & \\
\hline & & & & & & & & & $\begin{array}{c}\mathrm{kg} / \mathrm{p} \\
\text { kg/day }\end{array}$ & $\begin{array}{l}\mathrm{r}-\% \\
\text { Fat } \%\end{array}$ \\
\hline \multicolumn{11}{|l|}{1959} \\
\hline I A & & & & 1 & 9 & 5 & 1 & 16 & 18.6 & 4.6 \\
\hline B & 1 & 3 & 7 & 8 & & & & 19 & 7.9 & 5.2 \\
\hline II & 3 & 2 & 8 & 6 & 8 & 4 & 1 & 32 & 12.0 & 4.7 \\
\hline III & 3 & 2 & 7 & 10 & 7 & 3 & 1 & 33 & 11.8 & 4.6 \\
\hline $\begin{array}{l}\text { IV } \\
\qquad 1960\end{array}$ & 3 & 2 & 5 & 10 & 7 & 2 & 3 & 32 & 11.6 & 4.7 \\
\hline I A & & & & 7 & 8 & 4 & & 19 & 17.1 & 4.7 \\
\hline B & 3 & 1 & 6 & 6 & & & & 16 & 8.0 & 5.3 \\
\hline II & 1 & 2 & 8 & 13 & 4 & 4 & 2 & 34 & 12.9 & 4.7 \\
\hline III & 4 & 2 & 10 & 8 & 5 & 2 & 1 & 32 & 10.8 & 4.7 \\
\hline
\end{tabular}

Taulukko 2. Lehmien jakaantuminen eri luokkiin sen mukaan miten pitkä aika (p) niillä oli seuraavaan poikimiseen.

Table 2. Number of cows according to time until their next calving.

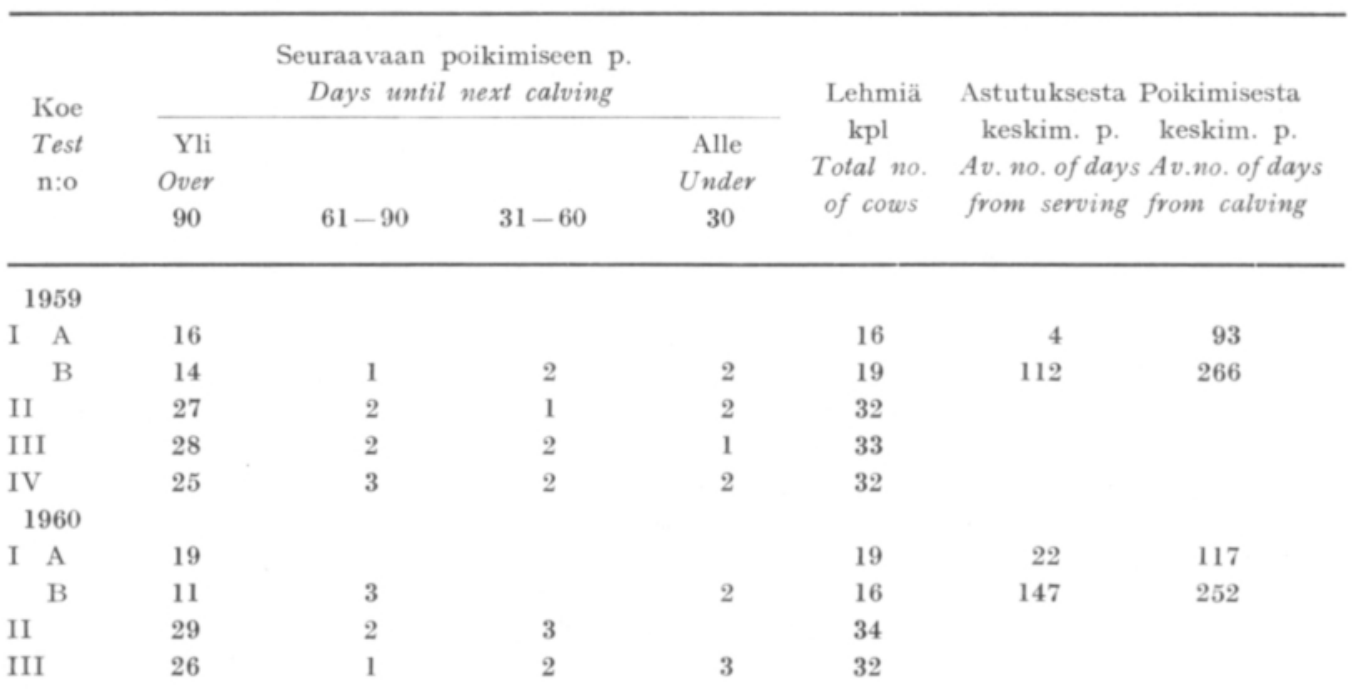

ja ruokasuolaa. Vähätuottoisten ryhmä söi eläintä kohti huomattavasti runsaammin muita kivennäisrehuja paitsi ruokasuolaa kuin runsastuottoiset. Mahdollista on, että edellisellä talvikaudella, jolloin nämä vähätuottoiset olivat runsastuottoisia, ei niiden kivennäisaineiden saanti ollut tarvetta vastaavaa, ja ne näinollen 
pyrkivät alkukesällä kivennäisaineiden saannin ollessa vapaata korjaamaan niiden vajauksen. Myös laitumen erilainen kasvikoostumus on voinut vaikuttaa tuloksiin. Seuraavana kesänä järjestettiin samanlainen koe ja tulos oli päinvastainen (s. 145). Rehusuolaseos IV sisälsi $50 \%$ mononatriumfosfaattia ja $40 \%$ rehufosfaattia. Huomattavaa on, että lehmät söivät tätä seosta suurempia määriä kuin edellisen vuoden kokeissa mononatriumfosfaattia pelkältään, vaikka toisena pääaineosana oli hyvin vähän haluttu (4) rehufosfaatti. Seuraavan vuoden kokeessa I (s. 146) vertailtiin rehusuolaseosta IV ja mononatriumfosfaattia, ja se osoitti, että jos jälkimmäistä on saatavana, se on halutuin kivennäisrehu.

K o e II. Kokeen aikana $(8 / 7-7 / 8)$ laidunnettiin aluksi 8 päivää nurminatatimoteivaltaisella laitumella, sitten 9 päivää koiranheinä-nurminatavaltaisella laitumella, sitten 13 päivää ensiksi mainitulla laitumella. Lisärehuksi saivat ne lehmät, joiden ravinnontarve maidontuotantoa varten oli yli 6 ry, kaura-vehnä seosta, jossa oli puolet kumpaakin.

Kokeessa saivat lehmät syödä vapaasti rehusuolaseosta V ja VI, luujauhoja ja ruokasuolaa. Rehusuolaseoksen $\mathrm{V}$ sisältämä $41 \%$ dinatriumfosfaattimäärä tai kalajauho on ilmeisesti tehnyt sen tämän kokeen halutummaksi rehuksi. Dinatriumfosfaatti ei kuitenkaan ole läheskään yhtä haluttua kuin mononatriumfosfaatti. Seoksen VI sisältämä $15 \%$ mononatriumfosfaattimäärä ei ole ollut riittävä tekemään seosta hyvin maittavaksi. Luujauhoja söivät lehmät tässä kokeessa huomattavasti vähemmän kuin aikaisemmissa kokeissa, vaikka se oli samaa erää kuin kokeessa I. Onko seoksen V kalajauho vaikuttanut siihen, ei kuitenkaan voida tämän kokeen perusteella päätellä. Molemmathan sisältävät myös orgaanisia aineita mm. valkuaista.

K o e III. Kokeen aikana $(7 / 8-26 / 8)$ laidunnettiin lehmiä aluksi 4 päivää nurminata-timoteivaltaisella laitumella ja loppuajan koiranheinä-nurminatavaltaisella laitumella. Kuuden viimeisen päivän aika oli sisäruokinta, koska laitumet loppuivat kuivuuden vuoksi. Ruokinta oli keskimäärin lehmää kohti päivässä: $4 \mathrm{~kg}$ väkirehuja (kaura, ohra, ruis, öljyväkirehuseos 5.5:4.5:2:2), $30 \mathrm{~kg}$ odelmaa, $4 \mathrm{~kg}$ heiniä, $1 \mathrm{~kg}$ ohranolkia.

Kokeessa vertailtiin ruokintakalkkia ja -liitua toisiinsa. Kumpaakaan eivät lehmät syöneet ollenkaan. Koe osoittaa myös, etteivät lehmät syö kuin hyvin vähän rehufosfaattia, vaikka se oli ainoana fosforirehusuolana. Käytettäessä näitä kivennäisrehuja laitumella jää kalsiumin ja fosforin saanti jokseenkin yksinomaan laidunrehun varaan.

K o e IV. Kokeen aikana $(26 / 8-25 / 9)$ lehmät olivat laitumella, mutta saivat lypsyn yhteydessä sisäruokinnan, koska laidunruohoa ei ollut. 25 päivän aikana oli ruokinta sama kuin edellisen kokeen lopussa. Viimeisten 5 päivän aikana oli ruokinta keskimäärin lehmää kohti päivässä: $5.5 \mathrm{~kg}$ väkirehuja (samat lajit kuin edellisessä, mutta suhteessa $7: 5: 3: 2), 30 \mathrm{~kg}$ lantun naatteja, $5.5 \mathrm{~kg}$ heiniä, $1.5 \mathrm{~kg}$ ohranolkea.

Kokeella haluttiin selvittää, kuinka paljon maittavammaksi saadaan sellainen rehusuolaseos, jota eivät lehmät syö pelkältään halukkaasti, lisäämällä siihen 
Taulukko 3. Lehmien syömät kivennäisrehumäärät v. 1959 suoritetuissa kokeissa (g/p eläintä kohti)

Table 3. Quantities of mineral fodders consumed by the cows in the 1959 trials. (g/day/animal).

\begin{tabular}{|c|c|c|c|c|c|c|c|c|}
\hline \multirow{5}{*}{$\begin{array}{l}\text { Test } \\
\mathrm{n}: \mathrm{o}\end{array}$} & \multirow{5}{*}{$\begin{array}{l}\text { Keski- } \\
\text { lehmä- } \\
\text { luku } \\
\text { Av. no. } \\
\text { of cows }\end{array}$} & \multirow{5}{*}{$\begin{array}{c}\text { Rehulaji } \\
\text { Fodder type }\end{array}$} & \multicolumn{6}{|c|}{ Syöty - Quantity consumed } \\
\hline & & & $\mathrm{Re}-$ & $\mathrm{Ca}$ & $\mathbf{P}$ & $\mathrm{Mg}$ & $\mathrm{Na}$ & $\mathrm{Na}$ \\
\hline & & & hua & & & & \multirow{2}{*}{\multicolumn{2}{|c|}{$\begin{array}{c}\text { laskettu } \\
\text { calc. } \\
\mathrm{NaCl}\end{array}$}} \\
\hline & & & Fodder & & & & & \\
\hline & & & g & g & g & g & g & g \\
\hline
\end{tabular}

I A 15.7 Rehusuolaseos IV - Mixture IV 52

Luujauho - Bone meal 31

Ruokasuola - Common salt $\quad 69$

\begin{tabular}{llllll}
\hline Yht. - Total & 13.1 & 12.0 & 1.3 & 32.8 & 83
\end{tabular}

I B 18.9 Rehusuolaseos IV - Mixture IV 139

Luujauho - Bone meal $\quad 37$

Ruokasuola - Common salt $\quad 29$

\begin{tabular}{llllll}
\hline Yht. - Total & 21.7 & 25.7 & 3.0 & 25.8 & 66
\end{tabular}

II $\quad 32.3$ Rehusuolaseos $\mathrm{V}-$ Mixture $V \quad 45$

" VI - v VI 10

Luujauho - Bone meal $\quad 7$

Ruokasuola - Common salt 41

\begin{tabular}{llllll}
\hline Yht. - Total & 8.3 & 7.0 & 1.4 & 19.5 & 50
\end{tabular}

III 32.5 Ruokintakalkki - Limestone -

Rehuliitu - Chalkstone

Rehufosfaatti - Dicalcium phosphate $\quad 3$

Ruokasuola - Common salt 36

\begin{tabular}{lllll}
\hline Yht. - Total & 0.8 & 0.5 & 14.2 & 36
\end{tabular}

IV 31.6 Rehusuolaseos I - Mixture I 11

$-\ldots+10 \%$ melassileikettä,$-+10 \% \quad 18$ 1

dried molasses beetpulp

$\rightarrow-+10 \%$ kaurajauhoja,$-+10 \%$

oatmeal $19^{1}$

$-\cdots+10 \%$ vehnänleseitä,$-+10 \%$

wheat bran 411

bran

Ruokasuola, hieno - Common salt, fine $\quad 44$

Ruokasuola, karkea - , , coarse 16

\begin{tabular}{lllll}
\hline Yht. - Total & 25.8 & 8.4 & 25.5 & 65
\end{tabular}

1 vain rehusuolaseoksen I kulutus only consumption of Mixture I 
$10 \%$ melassileikettä, $10 \%$ kaurajauhoja tai $10 \%$ vehnänleseitä. Samoin vertailtiin kokeessa hienoa ruokasuolaa ja hyvin karkeata suolaa. Seokseen lisätyistä rehuista on vehnänlese tehnyt seoksen halutuimmaksi. Melassileike ja kaurajauho ovat olleet saman veroiset. Tällaisia lisäaineita sekoittamalla saatiin lehmät syömään paremmin muutoin huonosti maittavaa rehusuolaseosta. Runsaampi syönti tapahtui pääasiassa kuitenkin vain 10 ensimmäisen päivän aikana. Tässä kokeessa saivat lehmät kuitenkin täyden sisäruokinnan ja myös väkirehuja (ei rehusuoloja), joten tämän kokeen perusteella jää selvittämättä, pystytäänkö laidunruokinnalla lisäämällä $10 \%$ väkirehuja rehusuolaseoksiin parantamaan edellistä enemmän seoksen kulutusta ja pitämään tämä kulutus jatkuvasti runsaana. Ruokasuolan kulutusnumerot osoittavat, että hieno suola on ollut lähes kolme kertaa halutumpaa kuin hyvin karkea suola.

\section{$\mathrm{H}$ i e hot}

Hiehoilla suoritettiin myös neljä koetta. Taul. 4 on esitetty tiedot kokeissa olleista hiehoista. Laidun oli sama kuin kahtena edellisenä kesänä suoritetuissa kokeissa, nimittäin nurminata-koiranheinävaltainen laidun, jossa apilapitoisuus oli vähentynyt alle $10 \%$. Tulokset on esitetty taulukossa 5 .

K o e I. Hiehoilla oli samat kivennäisrehut (rehusuolaseos IV, luujauho ja ruokasuola) tarjolla kuin lehmillä kokeessa I. Kokeen suoritusaika oli niinikään sama. Hiehot söivät eläintä kohti runsaammin kuin lehmät muita kivennäisrehuja paitsi ruokasuolaa. Mononatriumfosfaattia $(50 \%)$ sisältävää seosta IV ne söivät halukkaimmin.

Taulukko 4. Tietoja kokeissa olleista hiehoista.

Table 4. Data on heifers in the trials.

\begin{tabular}{|c|c|c|c|c|c|}
\hline \multirow{2}{*}{$\begin{array}{l}\text { Koe } \\
\text { Test } \\
\text { n:o }\end{array}$} & \multirow{2}{*}{$\begin{array}{l}\text { Lukumäärä } \\
\text { Number }\end{array}$} & \multirow{2}{*}{$\begin{array}{l}\text { Keski-ikä (v) } \\
\text { Average } \\
\text { age, years }\end{array}$} & \multirow{2}{*}{$\begin{array}{c}\text { Keskim. } \\
\text { elopaino }\end{array}$} & \multicolumn{2}{|c|}{ Astutettuja - Served } \\
\hline & & & & $\begin{array}{l}\text { Lukumäärä } \\
\text { Number }\end{array}$ & $\begin{array}{c}\text { Astutuksesta } \\
\text { keskimäärin } \\
\text { Av.time from } \\
\text { serving } \\
\mathrm{p}-\text { days }\end{array}$ \\
\hline \multicolumn{6}{|l|}{1959} \\
\hline I & 17 & 1.5 & 364 & 9 & 112 \\
\hline II & 17 & 1.6 & 382 & 9 & 142 \\
\hline III & 17 & 1.7 & 400 & 9 & 167 \\
\hline IV & 15 & 1.6 & 395 & 8 & 176 \\
\hline \multicolumn{6}{|l|}{1960} \\
\hline I & 19 & 1.2 & 348 & 6 & 89 \\
\hline II & 21 & 1.4 & 342 & 6 & 109 \\
\hline III & 21 & 1.5 & 348 & 6 & 124 \\
\hline
\end{tabular}


Taulukko 5. Hiehojen syömät kivennäisrehumäärät v. 1959 suoritetuissa kokeissa (g/p eläintä kohti)

Table 5. Quantities of mineral fodders consumed by heifers in the 1959 trials. ( $/$ /day/animal).

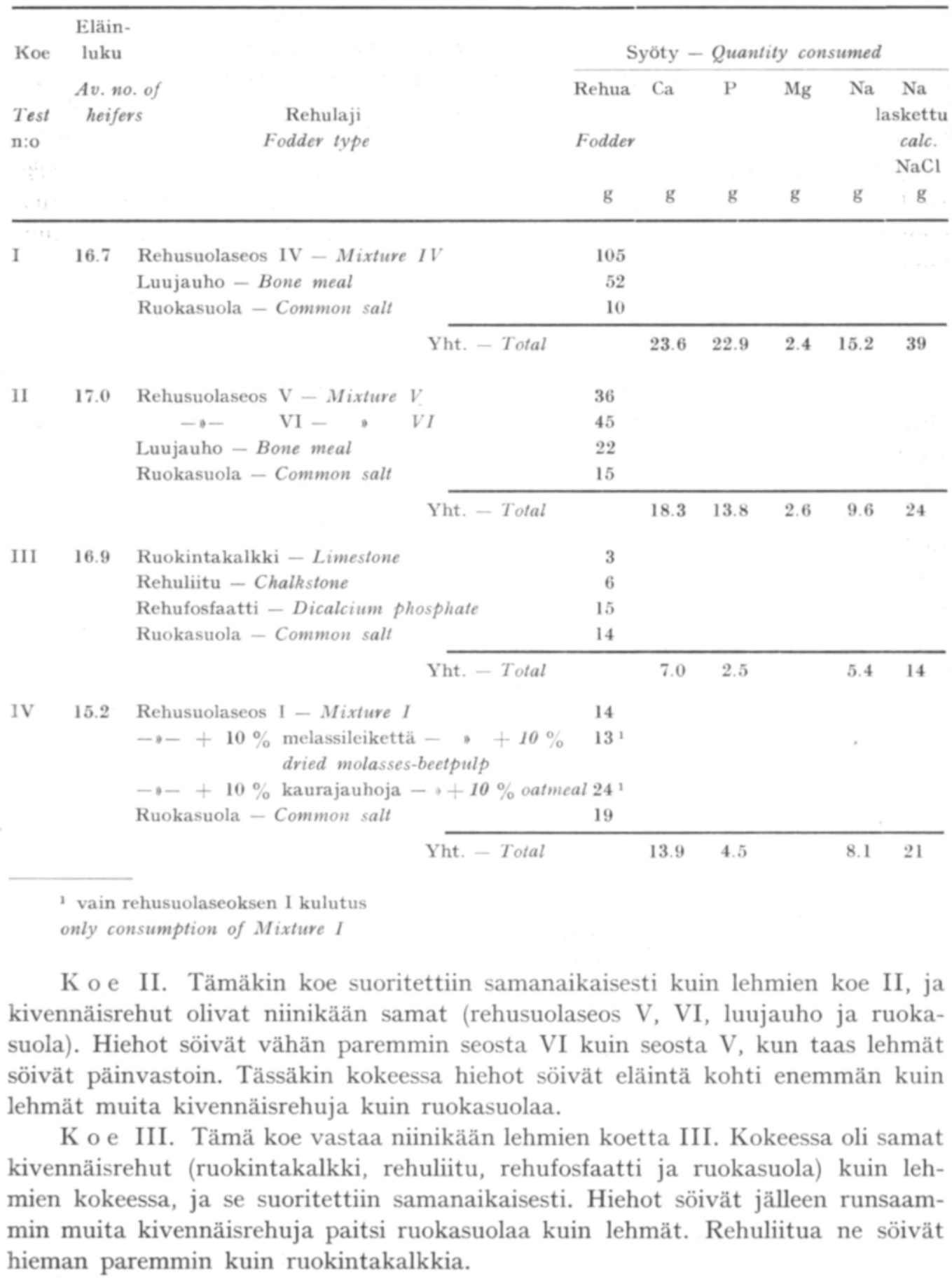


K o e IV. Tämä koe vastaa lehmien koetta IV. Hiehoilla oli kuitenkin tarjolla vain rehusuolaseosta $I$, seosta $I+10 \%$ melassileikettä, seosta $I+10 \%$ kaurajauhoja ja ruokasuolaa. Melassileikelisä ei ainakaan näytä lisänneen seoksen I syöntiä ja kaurajauhotkin lisäsivät sitä vain 10 ensimmäisen päivän aikana. Lehmillä oli vastaavan kokeen aikana sisäruokinta, kun taas hiehot olivat laidunruokinnalla. Vasta viimeisten 10 päivän aikana ne saivat lisärehuksi odelmaa $(500 \mathrm{~kg} / \mathrm{p})$.

\section{Vuoden 1960 kokeet}

\section{L e h m ät}

Lehmien keskimääräinen elopaino oli $522 \mathrm{~kg}$ ja keski-ikä $5.8 \mathrm{v}$. Lehmien lukumäärä ja jakaantuminen eri tuotosluokkiin eri kokeissa on esitetty taul. 1. Taul. 2 on lehmät ryhmitetty sen ajan (p) mukaan, mikä niillä oli jäljellä seuraavaan poikimiseen. Lehmillä suoritettiin kesän kuluessa kolme koetta, joista tulokset on esitetty taul. 6 .

K o e I. Koetta $(30 / 5-9 / 7)$ varten jaettiin karja kahteen ryhmään runsastuottoisiin (A) ja vähätuottoisiin (B). Kumpaakin ryhmää laidunnettiin nurminata-timoteivaltaisella laitumella. Kokeen aikana saivat kaurajauhoja ja heiniä lisärehuksi ne lehmät, joiden ravinnontarve maidontuotantoa varten oli yli 7 ry.

Kokeessa sai kumpikin ryhmä syödä vapaasti rehusuolaseosta IV, mononatriumfosfaattia, ruokintakalkkia ja ruokasuolaa. Aikaisemmissa kokeissa $(4 \mathrm{ja}$ s. 142) söivät lehmät suunnilleen samanlaisia määriä seosta IV (50\% mononatriumfosfaattia ja $40 \%$ rehufosfaattia) ja mononatriumfosfaattia silloin kun niitä ei ollut yhtäaikaa saatavissa. Tässä kokeessa osoittautui mononatriumfosfaatti seosta IV halutummaksi kun niitä oli samanaikaisesti saatavissa. Tässä kokeessa runsastuottoiset lehmät söivät selvästi enemmän kivennäisrehuja kuin vähätuottoiset. Edellisenä vuonna suoritetussa vastaavanlaisessa kokeessa (koe I s. 142) asia oli muuten päinvastainen paitsi ruokasuolaan nähden. Saattaa olla, että edellisen sisäruokintakauden kivennäisaineiden saanti on aiheuttanut erilaiset tulokset.

K o e II. Kokeen aikana $(9 / 7-18 / 8)$ laidunnettiin lehmiä samoilla lohkoilla kuin edellisessäkin kokeessa. Lisäruokinta oli niinikään sama.

Lehmät saivat syödä vapaasti rehusuolaseoksia I ja VII. Tällä kokeella haluttiin selvittää, tekeekö ruokasuola vähemmän maittavista raaka-aineista tehdyn seoksen halutummaksi, jos ruokasuolaa ei anneta erikseen. Aikaisemmassa kokeessa (3, koe I) oli melkein samanlainen seos hyvin vähän haluttu, kun ruokasuolaa oli erikseen tarjolla. Koe osoittaa, että ruokasuola parantaa seoksen maittavuutta siinä tapauksessa, ettei sitä anneta erikseen. Niin paljon ruokasuolaa ne eivät kuitenkaan syöneet seoksessa, kuin mitä ne pelkältään annettuna haluavat sitä syödä.

K o e III. Kokeen aikana $(18 / 8-17 / 9)$ laidunnettiin lehmiä samoilla lohkoilla kuin edellisessäkin kokeissa 19 ensimmäistä päivää ja 11 viimeistä päivää 
Taulukko 6. Lehmien syömät kivennäisrehumäärät v. 1960 suoritetuissa kokeissa (g/p eläintä kohti)

Table 6. Quantities of mineral fodders consumed by cows in the 1960 trials. (g/day/animal).

\begin{tabular}{|c|c|c|c|c|c|c|c|c|}
\hline \multirow{2}{*}{$\begin{array}{l}\text { Koe } \\
\text { Test }\end{array}$} & \multirow{2}{*}{$\begin{array}{l}\text { Keski- } \\
\text { lehmä- } \\
\text { luku }\end{array}$} & & \multicolumn{6}{|c|}{ Syöty - Quantity consumed } \\
\hline & & & Rehua & $\mathrm{Ca}$ & $\mathrm{P}$ & $\mathrm{Mg}$ & $\mathrm{Na}$ & $\mathrm{Na}$ \\
\hline \multirow[t]{2}{*}{ n:o } & $\begin{array}{l}\text { Av. no. } \\
\text { of cows }\end{array}$ & $\begin{array}{c}\text { Rehulaji } \\
\text { Fodder type }\end{array}$ & \multicolumn{6}{|c|}{$\begin{array}{c}\text { laskettu } \\
\text { calc. }\end{array}$} \\
\hline & & & g & g & g & $\mathrm{g}$ & g & g \\
\hline
\end{tabular}

I A 19.4 Rehusuolaseos IV - Mixture IV 36

Mononatriumfosfaatti - Monosodium

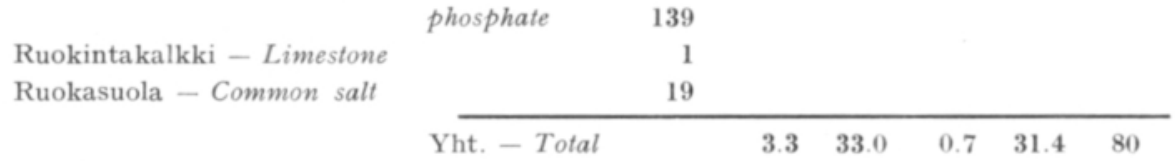

I B 16.1 Rehusuolaseos IV - Mixture IV

11

Rononatriumfosfaatti - Monosodium

phosphate $\quad 112$

Ruokintakalkki - Limestone $\quad 2$

$\begin{array}{ll}\text { Ruokasuola - Common salt } & 17\end{array}$

\begin{tabular}{llllll}
\hline Yht. - Total & 1.4 & 23.9 & 0.2 & 20.3 & 52
\end{tabular}

II

34.3 Rehusuolaseos I - Mixture I

Rehusuolaseos VII - , VII

10

\begin{tabular}{lllllll}
\hline Yht. - Total & & 15.1 & 10.7 & 4.5 & 8.8 & 22
\end{tabular}

III

$\begin{array}{lr}\text { Ruokintakalkki - Limestone } & 4 \\ \text { Ruokintadolomiitti - Dolomite limestone } & 4 \\ \text { Rehusuolaseos IV - Mixture IV } & 108 \\ \text { Ruokasuola, hieno - Common salt, fine } & 22 \\ \text { Ruokasuola, tavallinen - , ordinary } & 21\end{array}$

Yht. - Total

$\begin{array}{lllll}10.6 & 16.1 & 2.5 & 27.6 & 70\end{array}$

uudella laitumella, joka kasvikoostumukseltaan oli apilapitoisempi kuin edelliset laidunlohkot. Lisärehua (kaura-ohra seosta) saivat ne lehmät, joiden ravinnontarve maidontuotantoa varten oli yli 6 ry. Odelmaa saivat lehmät keskimäärin n. $12 \mathrm{~kg} / \mathrm{p}$ eläintä kohti.

Tässä kokeessa vertailtiin ruokintakalkin ja -dolomiitin syöntiä sekä hienon ruokasuolan ja tavallisen ruokasuolan syöntiä. Kummassakaan vertailussa ei esiintynyt eroja. Voidaan todeta että sellaisenaan ruokintakalkki, -dolomiitti ja aikaisemmassa kokeessa (koe III 1959, s. 142) vertailtu rehuliitu ovat kaikki hyvin vähän haluttuja kivennäisrehuja laitumella. Tavallinen eläimille käytetty ruokasuola on yhtä hyvää kuin hienompi suola. Sen sijaan erittäin karkeata suolaa eivät lehmät syö yhtä halukkaasti kuin edellisiä (koe IV, 1959 s. 142). 
Taulukko 7. Hiehojen syömät kivennäisrehumäärät v. 1960 suoritetuissa kokeissa $(\mathrm{g} / \mathrm{p}$ eläintä kohti)

Table 7. Quantities of mineral fodders consumed by heifers in the 1960 trials (g/day/animal).

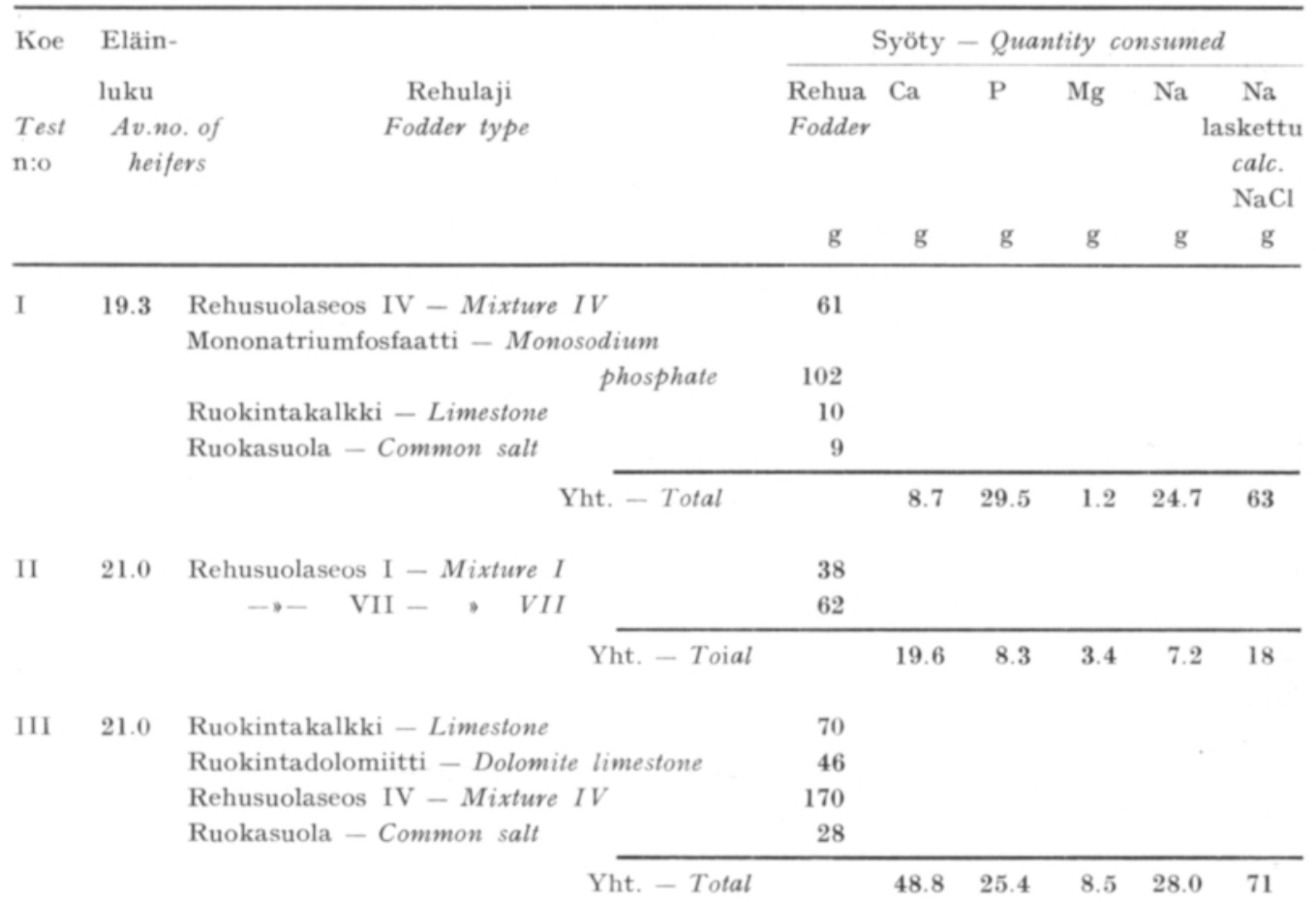

Hi e hot

Hiehoilla suoritettiin myös kolme koetta. Taul. 4 on esitetty tiedot kokeissa olleista hiehoista. Laidun oli sama kuin kaikissa kolmena edellisenä kesänä suoritetussa kokeessa. Tulokset on esitetty taul. 7 .

K o e I. Hiehoilla oli samat kivennäisrehut (rehusuolaseos IV, mononatriumfosfaatti, ruokintakalkki ja ruokasuola) saatavana kuin lehmillä kokeessa I. Kokeen suoritusaika oli niinikään sama. Mononatriumfosfaatti oli halutumpi kuin seos, jossa oli $50 \%$ mononatriumfosfaattia ja $40 \%$ rehufosfaattia.

K o e II. Kokeessa on käytetty samoja kivennäisrehuja (seokset I ja VII) kuin lehmien kokeissa II sekä suoritettu samanaikaisesti. Tämäkin koe osoitti, että ruokasuola tekee seoksen halutummaksi, jos sitä ei anneta erikseen. Suolan kulutus jäi kuitenkin normaalia vähäisemmäksi kuten lehmienkin vastaavassa kokeessa.

K o e III. Tässä kokeessa on käytetty muutoin samoja kivennäisrehuja (ruokintakalkki, -dolomiitti, seos IV ja ruokasuola) kuin lehmien kokeessa III paitsi karkeampaa ruokasuolaa. Kokeen suoritusaika oli niinikään sama. Vaikka vastaa- 
vassa kokeessa lehmät söivät tuskin ollenkaan ruokintakalkkia ja -dolomiittia, niin hiehot sensijaan söivät niitä melko runsaasti. Sama havainto on tehty aikaisemmissakin kokeissa (4 ja s. 144), siis että hiehot syövät enemmän kalsiumpitoisia kivennäisrehuja kuin lehmät. Ruokintakalkin syönti oli runsaampaa kuin ruokintadolomiitin. Ensimmäisten 10 päivän aikana söivät hiehot seosta IV jopa $290 \mathrm{~g} / \mathrm{p}$ eläintä kohti. Mitään haitallisia vaikutuksia ei näin runsaastakaan syönnistä ollut havaittavissa.

Jos vertaamme hiehojen ja lehmien syömiä kivennäisrehumääriä voidaan todeta, että v. 1960 kokeissa hiehot ovat syöneet niitä enemmän kuin lehmät lukuunottamatta ruokasuolaa.

\section{Yhdistelmä vv. 1957-60 suoritetuista kokeista}

Lehmillä on suoritettu mainittuina vuosina kaikkiaan 11 koetta ja hiehoilla vastaavasti 10. Lehmien ja hiehojen kokeet ovat olleet muutoin samanlaisia, paitsi että jälkimmäisillä on kokeiltujen kivennäisrehujen lukumäärä ollut hieman pienempi. Lehmillä v. 1957 suoritettu koe I puuttuu hiehoilta, joten niiden v. 1957 koe I vastaa lehmien saman vuoden koetta II.

Taulukossa 8 on esitetty eri kokeissa lehmien ja hiehojen kivennäisrehuissa syömät $\mathrm{Ca}, \mathrm{P}, \mathrm{Na}$ ja NaCl-lasketut määrät eläintä kohti päivässä. Voidaan todeta, että eläinten syömät määrät vaihtelevat hyvin suuresti riippuen siitä, mitä kivennäisrehuja niillä on laitumella saatavissa. Laitumet olivat kokeiden aikana suunnilleen saman tyyppisiä kasvikoostumukseltaan ja esim. hiehojen laidun oli kaikkien kokeiden aikana sama. Kasvikoostumus tietenkin muuttui kuten yleensä laitumen vanhetessa siten, että esim. apilan osuus väheni ja rikkaruohojen lisääntyi. Sääsuhteita ei tutkimuksessa ole otettu huomioon, mutta samanlaisissakin sääolosuhteissa on kivennäisrehujen syönnin määrä riippunut pääasiassa niiden koostumuksesta.

Lehmillä on kalsiumin syönti kivennäisrehuissa vaihdellut 1 g:sta 26 g:aan päivässä eläintä kohti. Pienimmät määrät on saatu kokeista, joissa oli vain ruokintakalkkia, -liitua tai -dolomiittia ja rehufosfaattia sellaisenaan. Suurimmat määrät on saatu kokeista, joissa nämä raaka-aineet on sekoitettu mononatriumfosfaatin tai väkirehujen kanssa tai, joissa on ollut saatavana luujauhoja. KIvıMÄEN (1) kokeessa lehmät söivät annettaessa ruokintakalkkia ja rehufosfaattia erikseen yhteensä $4.7-5.6 \mathrm{~g} / \mathrm{p}$ kalsiumia.

Fosforin syönti on vaihdellut vastaavasti $1 \mathrm{~g}$ :sta $29 \mathrm{~g}$ :aan päivässä eläintä kohti. Pienimmäksi jää fosforin saanti silloin, jos vain rehufosfaattia on pelkältään saatavissa. Suurimmat määrät on saatu kokeista, joissa on käytetty mononatriumfosfaattia tai sitä $(50 \%)$ ja rehufosfaattia sisältävää seosta. Keskinkertaisia määriä saavat eläimet fosforia silloin kun on saatavana luujauhoja tai dinatriumfosfaattia. Fosforia söivät lehmät KIvıMÄEN kokeessa rehufosfaattia ja natriumfosfaattia erikseen annettaessa $4.0-11.5 \mathrm{~g} / \mathrm{p}$.

$\mathrm{NaCl}$ :ksi lasketun natriumin määrä on kokeissa vaihdellut $30-74 \mathrm{~g} / \mathrm{p}$ eläintä kohti. Poikkeuksellisen vähän $20 \mathrm{~g} / \mathrm{p}$ söivät eläimet silloin, kun ruokasuolaa ei 
Taulukko 8. Vv. 1957-60 suoritetuissa kokeissa nautakarjan kivennäisrehuissa syömät ainemäärät.

Table 8. Quantity of minerals consumed by cattle in trials during the years $1957-60$.

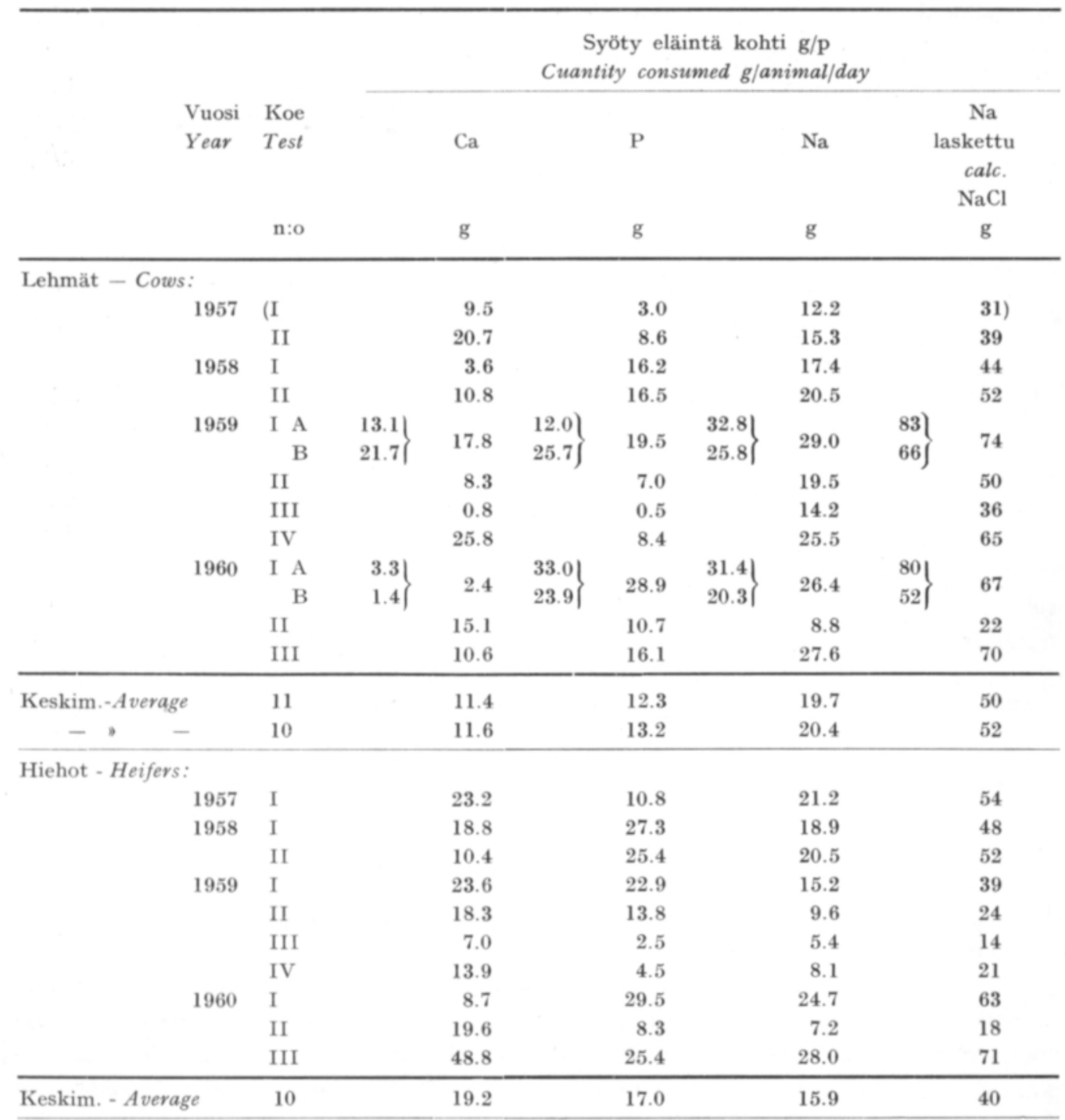

annettu erikseen, vaan muutoin huonosti maittavassa seoksessa. Suurimmat $\mathrm{NaCl}$ määrät on syöty niissä kokeissa, joissa on ollut mononatriumfosfaattia joko pelkältään tai $50 \%$ sitä sisältävää seosta ja ruokasuolaa vapaasti saatavissa. Vv. 1959-60 ei todettu samaa suuntausta kuin aikaisemmissa kokeissa että loppukesällä kulutus on suurempi kuin alkukesällä, vaan vaihtelu riippui pääasiassa käytetyistä kivennäisrehuista. Sмгтнin ym. (2) kokeissa lehmät söivät eri laiduntyypeillä ruokasuolaa keskimäärin 53-72 g/p ja kolmena eri vuonna keskim. 30$81 \mathrm{~g} / \mathrm{p}$ eläintä kohti, joten kulutus on ollut samaa suuruusluokkaa kuin tässä tutkimuksessakin. 
Hiehoilla suoritettujen kokeiden tulokset ovat suunnilleen samanlaiset kuin lehmillä suoritettujen. Huomattava on, että paitsi natriumia hiehot ovat syöneet keskimäärin suurempia määriä muita kivennäisaineita kuin lehmät. Kaikissa kokeissa (jos jätetään huomiotta lehmien 1957 koe I, jota ei hiehoilla ollut) ne söivät keskimäärin enemmän kalsiumia n. $8 \mathrm{~g} / \mathrm{p}$ eläintä kohti ja fosforia $\mathrm{n} .4 \mathrm{~g} / \mathrm{p}$ kuin lehmät. $1-2 \mathrm{v}$. vanhat hiehot söivät Sмıтнin ym. kokeessa ruokasuolaa $28 \mathrm{~g} / \mathrm{p}$ ja $2-3$ v. vanhat $37 \mathrm{~g} / \mathrm{p}$, mikä on vähemmän kuin näissä kokeissa (keskim. $40 \mathrm{~g} / \mathrm{p}$ ).

\section{Yhteenveto}

Tutkimus on jatkoa aikaisemmin julkaistuille kokeille $(3,4)$. Lehmillä ja hiehoilla suoritettiin kummillakin v. 1959 neljä koetta ja v. 1960 kolme koetta. Kaikki rehusuolat olivat vapaasti saatavissa katollisissa kaukaloissa laitumella.

V. 1959 suoritetut kokeet. Kokeissa I oli lehmillä ja hiehoilla saatavana rehusuolaseosta IV, luujauhoja ja ruokasuolaa. Lehmät oli jaettu kahteen ryhmään: runsastuottoisiin ja vähätuottoisiin. Tässä kokeessa vähätuottoisten ryhmä söi eläintä kohden runsaammin muita kivennäisrehuja paitsi ruokasuolaa kuin runsastuottoisten ryhmä. Syy siihen voi olla peräisin edelliseltä sisäruokintakaudelta ja laidunlohkojen erilaisuudesta. Vrt. koe I 1960. Hiehoilla oli muiden kivennäisrehujen paitsi ruokasuolan kulutus keskimäärin suurempi kuin lehmillä. 50 \% mononatriumfosfaattia seoksessa tekee sen halutuksi.

Kokeissa II oli saatavana rehusuolaseosta V ja VI, luujauhoja ja ruokasuolaa. Seoksen V sisältämä $41 \%$ dinatriumfosfaattimäärä tai kalajauho on ilmeisesti tehnyt sen lehmille tämän kokeen halutuimmaksi rehuksi. Dinatriumfosfaatti ei ole kuitenkaan yhtä haluttua kuin mononatriumfosfaatti. Seoksen VI sisältämä $15 \%$ mononatriumfosfaattimäärä ei ole ollut riittävä tekemään seosta hyvin maittavaksi. Hiehot söivät kuitenkin hieman paremmin seosta VI kuin seosta V. Johtuuko luujauhojen tavallista pienempi kulutus tässä kokeessa mahdollisesti seoksen V sisältämistä kalajauhoista, sitä ei voida päätellä tämän kokeen perusteella. Molemmathan sisältävät myös orgaanisia aineita mm. valkuaista.

Kokeissa III oli saatavana ruokintakalkkia, rehuliitua, ruokintafosfaattia ja ruokasuolaa. Rehuliitu on tuskin ruokintakalkkia maittavampaa, koska kumpaakaan lehmät eivät syöneet ollenkaan ja hiehotkin vain hyvin vähän. Rehufosfaattikaan ei ole haluttua rehua pelkältään, kuten jo aikaisemmissakin kokeissa on todettu.

Kokeissa IV oli saatavana rehusuolaseosta I pelkältään, seosta I $+10 \%$ melassileikettä, seosta I + $10 \%$ kaurajauhoja tai seosta I + $10 \%$ vehnänleseitä. Hiehoilta puuttui viimeksimainittu seos. Rehut oli sekoitettu seoksen I kanssa. Vehnänlese teki seoksen halutuimmaksi lehmillä. Melassileike ja kaurajauho ovat olleet saman veroiset. Runsaampi syönti tapahtui pääasiassa kuitenkin vain 10 ensimmäisen päivän aikana. Tässä kokeessa saivat lehmät olosuhteiden pakosta lypsyn yhteydessä runsaasti väkirehuja, joten laidunruokinnalla väkirehuista ja kivennäisrehuista tehdyt seokset voivat olla paremmin haluttuja. Hiehot söivät paremmin rehusuolaseosta, johon oli sekoitettu kaurajauhoja kuin melassileikkeestä ja rehu- 
suolaseoksesta tehtyä seosta. Kulutus oli suurempi kuitenkin vain 10 ensimmäisen päivän aikana. Lehmillä vertailtiin samassa kokeessa myös hienon ja hyvin karkean ruokasuolan syöntiä. Hienoa suolaa ne söivät runsaammin kuin karkeata.

V. 1960 suoritetut kokeet. Kokeissa I verrattiin rehusuolaseoksen IV (50\% mononatriumfosfaattia, $40 \%$ rehufosfaattia) ja mononatriumfosfaatin syöntiä toisiinsa. Eläimet söivät halukkaammin jälkimmäistä kuin edellistä. Jos sitä ei ole eläimillä saatavissa, syövät ne runsaita määriä myös ensiksi mainittua (koe I 1959, III 1960). Tässä kokeessa runsastuottoiset lehmät söivät kivennäisrehuja runsaammin kuin vähätuottoiset.

Kokeissa II ei annttu ruokasuolaa erikseen kuten kaikissa muissa kokeissa, vaan sellaista seosta, johon oli lisätty $29.6 \%$ ruokasuolaa. Seoksen muut pääaineosat olivat huonosti maittavia. Lehmät ja hiehot haluavat syödä laitumella ruokasuolaa, ja jos sitä ei ole vapaasti saatavissa, ne syövät seosta, jossa sitä on runsaasti. $\mathrm{NaCl}$ :n syönti jäi tässä kokeessa kuitenkin normaalia pienemmäksi.

Kokeissa III verrattiin ruokintakalkin ja -dolomiitin syöntiä sekä lehmillä hienon ja tavallisen (keskikarkea) ruokasuolan syöntiä. Kummassakaan vertailussa lehmillä ei saatu eroja. Hiehot söivät enemmän ruokintakalkkia kuin -dolomiittia ja runsaammin kuin lehmät muita kivennäisrehuja paitsi ruokasuolaa.

Tähän asti suoritetuista kokeista (v. 1957-60) voidaan todeta, että nautakarja syö kivennäisrehuja vapaasti laitumella hyvin erilaisia määriä riippuen pääasiassa siitä mitä kivennäisrehuja käytetään.

Kalsiumpitoisista kivennäisrehuista ovat ruokintakalkki, liitu, -dolomiitti ja rehufosfaatti lehmille huonosti maittavia, kun taas luujauho on paremmin maittavaa rehua. Sekoittamalla huonosti maittavat rehut esim. mononatriumfosfaatin kanssa, syövät eläimet niitä runsaasti. Hiehot syövät em. rehuja pelkältäänkin runsaammin kuin lehmät. Kokeissa käytetyistä fosforipitoisista kivennäisrehuista on mononatriumfosfaatti halutuin fosforirehu. Sen määrästä seoksessa riippuu kuinka haluttua seos on. Keskinkertaisen haluttuja fosforirehuja ovat luujauhot ja dinatriumfosfaatti. Huonoimmin syöty rehu on ollut rehufosfaatti pelkältään.

Ruokasuolaa haluaa nautakarja syödä laitumella. Jos kivennäusrehut sisältävät runsaasti natriumfosfaatteja, on ruokasuolan kulutus niiden sisältämän natriumin vuoksi vähäisempää, mutta kuitenkin syödyn natriumin kokonaismäärä on yleensä suurempi kuin ruokasuolaa yksinään natriumrehuna käytettäessä. Jos ruokasuolaa ei anneta vapaasti, vaan se sekoitetaan pääasiassa ruokintakalkkia ja rehufosfaattia sisältävään seokseen, jää syöty natriumkloridimäärä pieneksi.

\section{KIRJALLISUUTTA}

(1) Кгviмäe, A. 1949, Phosphorous and calcium consumption by dairy cows on pastures. Apophoreta Tartuensia s. 318-323. Stockholm.

(2) Smith, S. E. \& Lengemann, F. W. \& Reid, J. T. 1953. Block vs. loose salt consumption by dairy cattle. J. Dairy Sci. 35: 762-765.

(3) UotılA, I. 1958. Nautakarjan kivennäisaineiden syönnistä laitumella. I. Referate: On the mineral matter consumption of neat on pasture I. Maat.tiet. aikak. 30: 189-198.

(4) - 1959. Nautakarjan kivennäisaineiden syönnistä laitumella. II. Referate: On the mineral matter consumption of neat on pasture. II. Ibid. 31: 149-161. 
Sum m a r y :

\title{
STUDIES ON THE SUPPLEMENTARY MINERAL CONSUMPTION OF CATTLE ON PASTURE. III
}

IRJA UOTILA

\author{
Agricultural Research Centre, Department of Animal Husbandry, Tikkurila
}

The present study is a continuation of previous investigations $(3,4)$ in which trials were carried out on the mineral consumption of milk cows and heifers on pasture.

In 1959 four trials were carried out with cows (Ayrshire breed) and four with heifers; in 1960 three trials were performed with each group. All of the mineral fodders were freely available to the animals under covered feeding troughs. The mean weight of the cows in 1959 was $507 \mathrm{~kg}$ and their mean age 6.1 years; in 1960 the corresponding figures were $522 \mathrm{~kg}$ and 5.8 years. Tables 1 and 2 present information on the cows used in the trials and Table 4 gives data on the heifers.

Tria $1 \mathrm{~s}$ in 1959 . Results from these trials are shown in Tables 3 and 5 . In Trial $\mathrm{I}(8 / 6-8 / 7)$ the cows were divided into two groups, high producers (A) and low producers (B). Group A grazed on a pasture dominatẹ by meadow fescue and timothy, whereas the pasture of Group B was mainly a cocksfoot-meadow fescue pasture. Those cows whose feed requirements for milk production were over 7 feed units received supplementary concentrates in the form of oatmeal and dried molasses-beet pulp. In this trial the low-producing group (B) consumed more mineral fodders excluding common salt than the high-producing group. (Compare Trial I, 1960). The presence of $50 \%$ monosodium phosphate in the fodder mixture made it palatable to the animals. In the case of the heifers, their mineral consumption with the exception of common salt was greater on the average than that of the cows.

In Trial II $(8 / 7-7 / 8)$ the animals were given fodder salt mixtures V and VI, bone meal and common salt. Mixture V was preferred to the cows, evidently because of its $41 \%$ content of disodium phosphate. In general this salt is not as readily eaten by cows as is monosodium phosphate, but in Mixture VI the content of monosodium phosphate was too low (only $15 \%$ ) to make this mixture expecially palatable to the cows. The heifers, however, consumed more of Mixture VI than V.

In Trial III $(7 / 8-26 / 8)$ limestone and chalkstone were compared with one another. The cows ate neither of these and the heifers only slight amounts, so that there was scarcely any difference in the palatability of these two fodders.

In Trial IV (26/8-25/9) the poorly-tasting Mixture I was given additions of $10 \%$ dried molasses-beet pulp, $10 \%$ oatmeal or $10 \%$ wheat bran. In the case of the heifers, the latter fodder was not used. The additions made the mixture more palatable to the animals, but the increase in consumption was evident mainly during only the first 10 days of the trial. Since the cows otherwise received large amounts of concentrates during this trial, this fact may explain why their mineral fodder consumption soon declined. In this same trial comparisons in the consumption of fine and coarse salt were made. The cows were found to prefer the fine salt.

Trials in 1960 . Results of these trials are shown in Tables 6 and 7 . In Trial $1(30 / 5-9 / 7)$ comparisons were made between the fodder salt mixture IV (50\% monosodium phosphate, $40 \%$ dicalcium phosphate) and monosodium phosphate. The animals ate the latter much more willingly than the former. If, however, monosodium phosphate is not available, the cattle eat large amounts of the former salt mixture, as was the case in Trial I in 1959 and Trial III in 1960. In this trial the high-producing cows consumed more total minerals than the low-producing cows.

In Trial II $(\mathbf{9} / \mathbf{7}-\mathbf{1 8 / 8})$ common salt was not given separately as in all the other trials, but it was prowided in the fodder salt mixture VII which contained $29.6 \% \mathrm{NaCl}$. This mixture was otherwise similar to the poorly-tasting Mixture I. Cattle on pasture desire to eat common salt, and if it is not available as such, they will eat the fodder mixture which contains it most abundantly. Thus in this trial Mixture VII was preferred to Mixture I. The consumption of $\mathrm{NaCl}$, however, was smaller than in the other trials. 
In Trial III (18/8-17/9) comparisons were made between limestone and dolomite limestone and in the case of cows also between fine and ordinary common salt. The cows consumed equal amounts of each of the two fodder forms, whereas the heifers consumed more limestone than dolomite limestone.

Table 8 presents summarized data on the trials carried out in the years 1957-60. During the trial period the plant composition of the pastures was approximately the same, and that of the heifers was the same pasture in all years (its clover content, however, decreased and its weed content increased). Cattle on pasture consume mineral fodders which vary widely in quantity; their consumption depends mainly on the kind of mineral fodder. The consumption of calcium by cows varied between 1 and 26 grams, that of phosphorus $1-29 \mathrm{~g}$ and that of sodium $9-29 \mathrm{grams}$.

Of the fodders containing calcium, limestone, chalkstone, dolomite and dicalcium phosphate are poorly-tasting to cows, whereas bone meal is preferred by them. By mixing for example monosodium phosphate with poorly-tasting mineral fodders, they become more palatable and the cattle will eat them readily. Heifers eat more of the above-mentioned poorly-tasting fodders than cows.

Of the phosphorus-containing fodders, monosodium phosphate is most favored by cattle. Its quantity in the fodder mixture has a direct effect on the palatability of the mixture. Phosphate fodders of moderate palatibility are bone meal and disodium phosphate. Dicalcium phosphate is eaten least willingly by cattle.

Cattle want to eat common salt on pasture. If the mineral fodders contain abundant sodium phosphates, the consumption of common salt is less because of the presence of sodium in the fodder. In this case the total quantity of sodium consumed is greater than when $\mathrm{NaCl}$ as such is the only source of sodium. If common salt is not provided separately, but is mixed with fodders containing principally limestone and dicalcium phosphate, the total consumption of sodium chloride remains small. 